\title{
Regional order and peaceful change: Security communities as a via media in international relations theory
}

Cooperation and Conflict 2014, Vol. 49(4) 519-535

(C) The Author(s) 2014

Reprints and permissions: sagepub.co.uk/journalsPermissions.nav DOI: $10.1177 / 00108367 \mid 3517570$ cac.sagepub.com @SAGE

\section{Simon Koschut}

University of Erlangen-Nuremberg, Germany

\begin{abstract}
The security community concept generally inhabits a rather small niche in the study of International Relations, as the logic of community fundamentally challenges the prevailing logic of anarchy. In this article, it is argued both on ontological and theoretical grounds that the concept's intellectual heritage and depth transcends the boundaries of existing theories. In this sense, the concept of security community serves as a via media by linking different strands of International Relations theory together and by bridging various theoretical gaps. This argument will be developed in two steps. Firstly, it will be shown that the security community framework developed by Karl W Deutsch is deeply rooted in International Political Theory without belonging to one particular branch. By locating the concept in International Political Theory, an exercise that has been neglected by the security community literature; it will be secondly demonstrated that the concept of security community takes the middle ground between specific strands of International Relations theory, as these strands are ultimately based on concepts of moral philosophy.
\end{abstract}

\section{Keywords}

International Political Theory, International Relations theory, regional order, security community

\section{Introduction}

The Deutschian concept of security community has become an inherently eclectic concept that claims a relatively small niche in International Relations (IR). It has been adopted and adapted by various strands of IR theory, however, mostly to serve their own purposes (e.g. the English School, Democratic Peace theory, Constructivism). ${ }^{1}$ Some scholars have argued that the concept of a (pluralistic) security community actually marks the introduction of a new paradigm in IR theory by promising the possibility of

\footnotetext{
Corresponding author:

Simon Koschut, University of Erlangen-Nuremberg, Findelgasse 7-9, 90402 Nuremberg, Germany.

Email: simon.koschut@fau.de
} 
peaceful change among nations (Adler and Barnett, 1998a; Lijphart, 1981). This article will take this latter argument further by claiming that the concept of security community serves as a via media in IR theory. This argument rests on the assumption that the concept of security community is deeply rooted in International Political Theory (IPT), a link that has been notoriously neglected by IR scholars. Consequently, the purpose of this article is to liberate the concept from its current niche existence by emphasizing its unique ontological and epistemological attributes that enable it to perform a unifying or 'sticking' function of linking different strands of IR theory together.

In order to develop this argument the article will begin first by explaining the concept of security community and by reviewing its intellectual evolution in IR (including its various theoretical adaptations). Secondly, it will reflect on the concept's origins in IPT. ${ }^{2}$ Locating the concept in IPT, an exercise that has been neglected by the security community literature, enables us to better search for the concept's theoretical grounding, as it is argued in this article, along with other scholars (Behr, 2010; Brown, 1992), that IR theory is ultimately based on and results from concepts of Political and Normative theory. Thirdly, the security community concept will be placed within the context of IR theory. Specifically, the article will look at how Classical Realist (Morgenthau, 1948), Structural Realist (Mearsheimer, 2001; Waltz, 1979), Neoliberal (Keohane and Nye, 1977), Neoliberal Institutional (Keohane, 1984) and Constructivist (Adler and Barnett, 1998b; Wendt, 1999) approaches, as well as the English School (Bull, 1977; Buzan, 2004) and Democratic Peace theory (Doyle, 1986; Russett, 1993; Starr, 1992), each deal with the issue of stable peace and community. ${ }^{3}$ Finally, the article will return to the previous assumptions and make some concluding remarks.

\section{What is a security community (and why should we bother)?}

A security community is considered to be 'a group that has become integrated, where integration is defined as the attainment of a sense of community, accompanied by formal or informal institutions or practices, sufficiently strong and widespread to assure peaceful change among members of a group with 'reasonable' certainty over a 'long' period of time' (Deutsch, 1954: 33). There is a rich and growing body of literature dealing with various facets and patterns of the concept of security community. Many scholars have made use of the concept and expanded its original scope in order to make it more applicable to the study of contemporary IR, broaden its empirical use and position it as an alternative concept to other forms of security governance and peaceful orders, such as alliances, regimes, international organizations (IOs) and imperial orders. Adler and Barnett's (1998a) path-breaking book is perhaps the best known scholarly work among others that combine the concept of security community with mainstream Constructivist approaches (Cronin, 1999; Bially Mattern, 2005; Risse-Kappen, 1996; Wendt, 1999).

To be sure, not all recent scholarly work on security communities has taken a strictly Constructivist turn. For instance, Väyrynen (2000) contrasts the security community concept to the concept of stable peace and criticizes Constructivist research for its limited attention to the material conditions of security communities. Mouritzen (2001) claims that both state and non-state actors can initiate security communities. Wiberg (2003) finds that security communities 'evolve from military alliances based on 
common threats'. Buzan and Wæver (2003) include the concept in their study on regional security complexes. Nathan (2006), Tusicisny (2007) and Roe (1999) underline the importance of domestic factors for maintaining a security community. Most recently, some scholars have aligned the concept of security community with the "practice turn' (Adler and Greve, 2009; Bjola and Kornprobst, 2007; Pouliot, 2008) and the 'emotion turn' (Koschut, 2013) in IR.

The concept of security community has recently transcended academic discourse by making its way into the area of policymaking. For example, since the end of the Cold war the North Atlantic Treaty Organization (NATO) has defined itself as a 'transatlantic security community' (Rasmussen, 2010). In October 2003, the member states of the Association of Southeast Asian Nations (ASEAN) announced its intention to create an 'ASEAN Security Community'. The ASEAN Vientiane Action Programme reads, 'ASEAN shall have, by the year 2020, established a peaceful and stable Southeast Asia where each nation is at peace with itself and where the causes for conflict have been eliminated, through abiding respect for justice and the rule of law and through the strengthening of national and regional resilience' (ASEAN, 2004: 6). Most recently, the Organization for Security and Co-operation in Europe (OSCE) formulated the goal of 'building a security community' (Zannier, 2012). Most of the concept's application, however, has been confined to academia where it has been used with growing frequency. Having outlined the concept's intellectual evolution in IR the article will now turn to its theoretical grounding in IPT before exploring its mediating role in IR theory.

\section{Security communities and International Political Theory}

Unnoticed by most scholars, the formation of community at the international level is deeply rooted in IPT, specifically in the famous dichotomy between Kantian cosmopolitanism and Hegelian communitarianism. As Behr (2010: 1) argues, this dichotomy in political philosophy has constituted and contextualized the discipline of IR and, more specifically, its ideas about war and peace. Hence, cosmopolitanism and communitarianism provide useful starting categories in order to subsequently locate the concept of security community in IR theory (Brown, 2010). The following overview does not pretend to cover all aspects of cosmopolitanism and communitarianism, respectively. Rather, it is meant to extract and highlight the clash between both strands of moral philosophy with regard to how both deal with the concept of community.

Cosmopolitans generally claim that all human beings share a common moral identity and thus are subject to existing universal normative standards and principles. From this moral cosmopolitanism derives the political goal of establishing a cosmopolitan political order that lies above and beyond the state system (Beitz, 1979; Dower, 1998: 23). In order to achieve equal moral standing as human beings, it is necessary to emancipate oneself from particular ties and loyalties that draw artificial boundaries between 'insiders' and 'outsiders' (Rawls, 1971). This understanding of cosmopolitanism is central to analysing concepts such as human security, humanitarian intervention or 'the responsibility to protect' and, since the rise of constructivism in IR, has become part of a cosmopolitan project of studying post-national identities, post-national citizenship and transnational public spheres (Archibugi, 2008; 
Beardsworth, 2011; Kaldor, 2003). In sum, cosmopolitans take a universalistic approach to the search for peace and security in IR.

Communitarians, ${ }^{4}$ on the contrary, generally argue that it is impossible to claim certain abstract moral standards and principles and to declare them as universally valid. Moreover, they question the feasibility of shedding particular ties and loyalties on the grounds that such particularities are an essential part of our identity that cannot be excluded. Instead, they look at the concrete practices, values and traditions of particular communities that provide the normative basis for action. Moreover, their approach does not question the ethical primacy of the state, which is why many IR Realists have (often implicitly) adopted a communitarian position (Dunne et al., 2010: 333; see also: Frost, 1986; Walzer, 1994). In sum, communitarians apply a particularistic approach to the study of international peace and security by accepting the plurality of cultural moral values: what Walzer (1994: x) once prominently labelled as the 'politics of difference'.

In short, cosmopolitans and communitarians essentially clash on the issue of community as the former views certain ethical standards, principles and values as universally applicable, while the latter holds that the particular collective acquires a special value (Walzer, 1994). This philosophical clash produces two main themes that carry relevance for the study of (security) community at the international level: system/society and universal/particular.

\section{System versus society}

How does the concept of security community fit into this dichotomy between communitarianism and cosmopolitanism? This section begins with the first theme: system versus society. Deutsch was deeply sceptical of any form of supra-state structure: 'the world is not ready for political amalgamation by the merger of national governments or by the creation of powerful international administrative agencies. At best, we can hope that pluralistic security communities among nations may develop' (Deutsch, 1968: 92). This puts him in close company with both communitarian approaches (communitarian realism) and Classical Realism in IR. ${ }^{5}$ However, the Deutschian framework clearly transcends the Realist paradigm by claiming that nations may establish a normative consensus of community to settle their disputes peacefully. In addition, Deutsch never limited himself to the analysis of inter-state relations but explicitly takes an individual-societal focus and bottom-up approach when he defines a security community as 'a group of people which has become integrated' (italics added; Deutsch et al., 1957: 5). Deutsch never understood IR to be strictly limited to the interaction between states but instead, as pointed out earlier, adopted a cybernetic approach focusing on transactions between individuals, groups and societies. In this sense, the concept of security community takes the theoretical middle ground. On the one hand, it accepts the realist proposition that international relations are organized as a system of states based on the distribution of material power and capabilities (international system), yet, on the other hand, emphasizes their social relationships based on shared understandings, principled belief systems and narratives - in short, the ideational and transnational conditions within a group (international society) (Buzan, 1993). 


\section{Universal versus particular}

This leads to the second theme: the universal versus the particular. At first glance, Deutsch's concept of security community appears utterly particularistic. Not only is Deutsch sceptical of any form of world government, but he also limits his studies to a distinct cultural and regional space (North Atlantic Area). This particularistic approach can also be found in the works of other recent authors who restrict the concept of security community to various but distinct cultural and regional spaces. ${ }^{6}$ Based on their findings, Adler and Barnett (1998c: 435) also remain sceptical of 'the world heading toward a security community "moment".

However, even though most empirical work on security communities has been conducted on particular regions, its theoretical implications point towards a more universalistic interpretation of the concept. A world consisting of regional security communities would, in theory, almost inevitably lead to an informal or formal 'global security community', as Bellamy (2004: 187) points out in his study on the relationship between security communities and their neighbours:

What is quite clear from the case studies and the analysis above is that the proliferation and integration of security communities do not represent the beginning of a Huntingtonian nightmare of a world of civilisational blocs in perpetual conflict with each other. Indeed, from the present argument we could deduce that the more security communities there are and the more tightly-coupled they become, the more blurred will be the boundaries between insiders and outsiders.

Bellamy bases this assumption on his earlier observation that the peaceful socialization of members within the security community not only reshapes the way community members view each other, but also transforms their worldview towards outsiders. In other words, the more the community members internalize the peaceful conduct of international affairs the more they will be willing to adopt a similar state of mind in their relations with non-members. This becomes even more compelling once members of one particular security community encounter members of another security community. Despite their regional and cultural differences, both would recognize each other as members of the same social order (Bellamy, 2004: 187). Hence, the proliferation of security communities is unlikely to create a conglomeration of 'regional fortresses' or 'gated communities' but rather forms the nucleus of a world society.

Eberwein (1995) and Russett (1998) also emphasize the possibility of global pacification through the establishment of regional security communities although, in contrast to Bellamy, they both base their assumptions on Democratic Peace theory. Even Deutsch himself, by envisaging a global model to determine and measure the political and economic development of humanity (GLOBUS), implicitly recognized this universalistic approach (Eberwein and Deutsch, 1990). Hence, it can be argued that the concept of security community is, at the same time, both particularistic and universalistic. In sum, based on the observations made above, it can be further argued that the concept of security community lies at the philosophical crossroads between cosmopolitanism and communitarianism. This has significant implications for its role and function in IR theory. 


\section{Security communities and international relations theory}

As argued above, the concept of security community has generally inhabited a rather small niche in the study of IR, as the logic of community fundamentally challenges the prevailing logic of anarchy. According to the latter logic, even though states might sporadically seek security cooperation, the anarchical nature of the international order drives states to inevitably act in a self-interested and self-help manner by seeking advantages over their counterparts, thus eliminating any prospect of dependable expectations of peaceful change. Of course, this orthodox reading of IR has already been challenged on many accounts. Still, the idea and language of community at the international level, despite its academic and political revival after the end of the Cold War, has yet to enter the mainstream intellectual discourse in the discipline of IR. The concept has been adopted and adapted by various 'schools' of IR theory, however, mostly to serve their own purposes. The following overview is not meant to represent the full spectrum of IR theory nor is it possible to cover each of the following theoretical strands in full depth. Rather, it is meant to elaborate on the meaning and role of community and stable peace in IR theory by placing the concept of security community within that context.

Structural Realism, both in its defensive (Waltz, 1979) and offensive (Mearsheimer, 2001) shape, is generally sceptical of the prospect of peaceful change because it sees only three logical ways to escape the security dilemma described above. The first option would be the establishment of a single world government to transform the current state of anarchy into a global social contract that resembles a universal form of sovereignty. However, Structural Realists view the concept of world government as unattainable, since it would require states to voluntarily limit their freedom of action. The second option lies at the other extreme and implies a perpetual war of all against all. This apocalyptical scenario is rejected on the grounds that state actors are not suicidal and will seek security arrangements that provide for a minimum of international stability and order. The third option involves a balance-of-power system. In this system, states seek security by maximizing their individual power capabilities through deterrence and the formation of alliances (Walt, 1996; Waltz, 1979). A Structural Realist variation of the balance-ofpower theory is the power transition theory based on power cycles of global or regional hegemony (Gilpin, 1981; Organski, 1968) Regardless of whether states will choose to match the power of others (balancing) or align with the most powerful hegemony (bandwagoning), structural changes in inter-state relations occur only through (often violent) shifts in the distribution of material power and capabilities.

According to Classical Realism, the cohesiveness of communities (both domestic and international) rests on the strength of communal bonds among human beings and not so much on the presence or absence of a strong central authority (Morgenthau, 1948; Thucydides, 431 BC/1989). Yet, both Thucydides and Morgenthau view communal bonds as fragile and that they can be easily undermined given the self-help manner of human nature. However, even Realism acknowledges the existence of a security community among the leading powers (United States, Western Europe, Japan) whose formation and maintenance is attributed at least in part to Realist explanations, such as American hegemony and nuclear deterrence (Jervis, 2002). 
Neoliberalism (Keohane and Nye, 1977) and Neoliberal Institutionalism (Keohane, 1984) also accept the anarchical state of the international system, but argue that the security dilemma can be regulated and thus limited through the establishment of IOs. IOs may provide information and transparency thereby reducing transaction costs, help to settle conflicts of interest peacefully, and limit cheating through the establishment of shared norms and rules (Keohane, 1989; Keohane and Nye, 1977). Neoliberalism and Neo-institutionalism both attempt to demonstrate that an anarchic environment is not necessarily limited to zero-sum games but that instead there are actually opportunities for mutual gain and cooperation if state actors choose to seek them. In the end, this may lead to peaceful interactions between states based on mutual interdependency. A slightly different view is offered by Liberal Intergovernmentalist theory, which stresses interstate bargaining based on issue-specific functional interests (Moravcsik, 1993). In this context, some Neoliberal Institutionalists have focused on the same variables used by Deutsch (Rosecrance, 1993).

For the study of peaceful change at the international level, (conventional) Constructivism (Adler and Barnett, 1998a; Katzenstein, 1996; Wendt, 1999) offers valuable insights. As outlined above, Constructivism generally argues that the structure of IR is not pre-determined by material factors but that social and ideational structures equally constitute an actor's preferences and identity. From this perspective, the state of anarchy appears as an empty vessel to be filled with the identities and interests of state and non-state actors. In turn, this implies that the seemingly anarchical nature of the international system can be changed by the preferences and identities of its actors (Wendt, 1992). While Constructivism includes a wide variety of different approaches, all tend to share the conception of giving equal importance to both non-material and material structures, the understanding that non-material structures can actually shape actors' preferences and, ultimately, their actions, and finally, the view that agents and structures are mutually constitutive (Reus-Smit and Price, 1998: 266). In contrast to critical (or consistent) Constructivists (Fierke, 2007; Mutimer, 1999; Weldes, 1999), who emphasize the flexible quality and essentially contested nature of norms and identities at the international level, conventional (or mainstream) Constructivists (Adler and Barnett, 1998b; Katzenstein, 1996; Wendt, 1999) focus on the relatively stable quality of norms and state behaviour within a community with a given identity. It is within the latter Constructivist framework that the security community concept is located, because ensuring 'dependable expectations of peaceful change' in a security community requires stable collective norms and identity that are able to transform the behaviour of states from a self-help manner to trust-building.

In sum, (conventional) Constructivists argue that the conditions of anarchy do not limit state actors to a self-help manner, but allow for other forms of behaviour based on the way actors perceive themselves and their social environment (Finnemore and Sikkink, 1998; Katzenstein, 1996; Onuf, 1989; Wendt, 1999). As a result, by adjusting their behaviour states may create the conditions under which stable, peaceful relations become not only possible but even likely. In doing so, they may establish a state of certainty and high levels of trust among each other.

While Constructivism provides valuable insights for community formation at the international level, it is by no means the exclusive source for explaining stable peace 
through the formation of community. Hedley Bull (1977: 13) and other scholars of the English School introduce the concept of an international society or a 'society of states' defined as 'a group of states, conscious of certain common interests and common values, (that) form a society in the sense that they conceive themselves to be bound by a common set of rules in their relations with one another and share in the working of common institutions'. The idea of an international society of states implies, contrary to the view that states inhabit a given international system, that they can recognize their membership in an international society through shared values, norms and rules. Given its obvious shared features, some proponents of the English School establish links to the Deutschian concept of security community by theorizing about 'islands of international society', 'mature anarchy' or simply 'zones of peace' (Buzan, 1993; Kacowicz, 1998).

There is a fundamental difference, however, between Deutsch's concept of a security community and Bull's idea of a society of states. Deutsch never understood IR to be limited to the interaction between states but adopted a cybernetic approach focusing on transactions between individuals, groups and societies (Deutsch, 1978). The English School, on the other hand, arguably never paid much attention to the role played by nonstate actors and the way they shape and influence IR (Reus-Smit, 2005: 94). Also, while acknowledging some of the basic questions raised by the concept of security community, Bull (1972: 42) criticizes Deutsch on methodological grounds for his 'fetish for measurement (and) indiscriminate collection of data about international politics'.

Finally, proponents of the Democratic Peace theory have explained stable peace by focusing on domestic preferences and regime type. The following overview does not pretend to be a comprehensive summary of their assumptions and findings. Rather, it seeks to explain some of the arguments that have been raised with regard to the study of pluralistic security communities. As early as 1795 , Immanuel Kant proposed the possibility of a 'pacific federation' or 'pacific union' among liberal republics. The main argument focuses on the distinct political culture of democracies based on individual rights and liberties as well as norms and preferences of orderly and peaceful conflict resolution within a domestic society that are externalized and exported into its international environment (Doyle, 1986; Russett, 1993; Slantchev, 2006). Whenever states and societies share the perception that they are liberal democracies, they are able to distinguish between likeminded democratic 'doves' and non-democratic 'non-doves' in the international sphere (Bueno de Mesquita and Lalman, 1992). As a result, liberal democratic states may form democratic zones of peace by building mutual trust and a democratic identity while, at the same time, separating themselves from the war-prone world of nondemocracies (Lipson, 2003; Werner and Lemke, 1997).

Some proponents of the Democratic Peace theory have thus linked their explanations directly to the Deutschian concept of security community by arguing that through processes of social learning and mutual recognition as liberal democracies, these states develop a collective democratic identity that plays a constitutive and disciplining role in the formation of 'democratic pluralistic security communities' (Bayer, 2010; Harrison, 2010; Risse-Kappen, 1995; Starr, 1992, 1997; Vasquez, 1995; Williams, 2001). Based on these assumptions, some of these authors have argued that democracy is essentially 'the basic requirement for integrated political security communities as defined by Deutsch' 
(Eberwein, 1995: 349; for a similar argument see also Risse-Kappen, 1996: 395; Starr, 1992: 210; Williams, 2001: 527).

However, the claim that democratic regime type needs to be treated as a necessary precondition for the formation of a security community must be handled with caution on both theoretical and empirical grounds. To begin with, the original concept of security community does not support this claim. Deutsch concludes that a consensus on 'main values' is sufficient (and necessary) in maintaining stable peace. He does not link this condition to any specific type of state organizing principle (Deutsch et al., 1957: 123). To restrict the concept of security community to liberal democratic types sets an unwarranted normative bias and unduly limits its intellectual utility and depth. For example, the Democratic Peace theory cannot explain the potential or actual development of pluralistic security communities among primarily non-democratic countries, raised by some scholars, such as the ASEAN, the Economic Community of West African States (ECOWAS) or the countries of the Southern African Development Community (SADC) (Acharya, 2001; Hammerstad, 2005; Kacowicz, 1998; Lund and Roig, 1999; Ngoma, 2003; Selebi, 1999; Shaw, 1998). In sum, liberal democratic values and political systems may certainly facilitate the formation of a security community, but it is by no means the only possible path (Koschut, 2012).

This abbreviated overview has shown that there are many possible ways to explain the formation of stable peace and community in IR theory. Structural Realism (Mearsheimer, 2001; Waltz, 1979) defines peaceful change primarily in terms of the ordering function of the international system through balance of power, alliances and deterrence. Neoliberal Institutionalism (Keohane, 1984) defines peaceful change more optimistically in terms of mutual gains through institutionalized cooperation and norms. Both Structural Realism and Neoliberalism (Keohane and Nye, 1977) share some of Deutsch's key variables, such as 'power' and 'interests'. Constructivism (Adler and Barnett, 1998b; Wendt, 1999) offers a promising intersection with the Deutschian concept by looking at changing social and normative interpretations of the material world through human interaction. Yet, by stressing the importance of norms, identity and language, Constructivist approaches only cover certain (albeit important) aspects of the Deutschian framework. The English School (Bull, 1977, Buzan, 2004) also shares some key characteristics with the security community concept, but it arguably neglects the role of transnational and non-state actors in the formation of international community. Burton's (1972) 'cob-web' image of a 'world society' shares some significant overlaps with and was developed in part based on Deutsch's security community concept. However, Deutsch rejects the idea that the Westphalian state system is becoming outmoded and gradually replaced by the development of a world society. Finally, Democratic Peace theory (Doyle, 1986; Russett, 1993; Starr, 1992), even though it provides some valuable insights into how security communities develop among democratic states, restricts itself to one particular regime type, which unnecessarily limits the Deutschian framework to only certain regions and societies.

In sum, the Deutschian security community is not simply a Grotian 'society of nations' in disguise nor can it be adequately captured by standard diplomatic categories, such as 'close', 'cordial' or 'friendly' relations between states. It also implies a much deeper relationship than forms of détente or rapprochement (Pentland, 1973: 39). Furthermore, 
it differs fundamentally from other strands of integration theory such as (Neo-) Functionalism, Federalism or Intergovernmentalism, all of which refuse to tie the concept of integration to one particular issue area, such as security, and argue that political community can only be established through supranational or federal institutions, in short: the existence of some kind of central authority (Etzioni, 1962: 3-13; Haas, 1958: 7; Hoffmann, 1963: 9-10). Even though Mitrany's (1943/1966) notion of a 'working peace system' does not presuppose the creation of a federal structure, Mitrany's functionalism rejects the geographical inside/outside dualism of a security community that is bound by territory: 'The only sound sense of peaceful change is (...) to make changes of frontiers unnecessary by making frontiers meaningless' (Mitrany, 1943/1966: 92).

For all these reasons, Vesa (1993: 160 and 164) rightly argues that the Deutschian framework for integration appears to be the least ambitious one, as it does not presuppose the existence of supranational organizations to replace the nation-state. Some authors have even claimed that Deutsch's approach to integration shares some of the key assumptions of Realism, including 'the belief that the nation-state is both the central fact of modern political life and the central focus of all political analysis' (Pentland, 1973: 35-36). To be sure, as outlined above, Deutsch was deeply sceptical of any form of world government (Deutsch, 1968: 92). At the same time, however, the Deutschian framework clearly transcends the Realist paradigm by claiming that nations may establish a normative consensus of community to settle their disputes peacefully. In this sense, the concept of security community is actually the most ambitious form of integration, since it implies that 'peace can be had in our time' (Deutsch, 1961: 190).

\section{Conclusion: security communities as a via media in International Relations theory}

This abbreviated appraisal of security community in IPT and IR theory has demonstrated two things. Firstly, it has shown that the Deutschian framework is deeply rooted in IPT without strictly belonging to one particular strand of moral philosophy. Specifically, the concept takes the middle ground between Kantian cosmopolitanism and Hegelian communitarianism. Secondly, and following from its roots in IPT, the security community concept takes the middle ground between various strands of IR theory, as these strands are ultimately based on classical concepts of Political theory (Brown, 2010: 35). Specifically, the Deutschian concept takes the middle ground between Realism (classical and structural) and Liberal Democratic theories, as it rejects the Realist notion that regime type is irrelevant to the study of international peace while simultaneously questioning the Liberal Democratic claim that a certain regime type serves as a prerequisite for peaceful IR. Security community further takes the middle ground between the statecentric view of both Neo-realism as well as Neoliberal approaches, on the one hand, and the social ontology of Postmodern and Reflectivist theories that examine the social interactions and social relations between states and non-state actors, on the other hand.

The question whether the Deutschian framework qualifies as a theory in its own right, however, is disputed and this article does not pretend to resolve this issue. Puchala (1981: 150 ), for example, argues that the security community concept is not a theory in itself but 
rather 'a set of assumptions about peace in IR'. Still, regardless of how one 'labels' or 'colours' the concept of security community in IR theory, this article made the point, both on ontological and theoretical grounds, that the concept's intellectual heritage and depth transcend the boundaries of existing theories and should thus be developed and explored further. For example, scholars could apply the concept more thoroughly to the non-Western, non-democratic world to see if peaceful integration among autocratic counterparts may be possible. Also, the security community concept is in desperate need for conditions and theoretical models that can explain processes of disintegration and decline. In this sense, the security community concept performs a unifying or 'sticking' function by providing docking points for many strands of IR theory. In the end, it serves as a via media by connecting different theoretical strands and bridging various theoretical gaps in IR.

\section{Funding}

This research received no specific grant from any funding agency in the public, commercial or not-for-profit sectors.

\section{Notes}

1. This article will rely on the formal distinction applied by Hollis and Smith (1990: 10) between theories in moral philosophy (lowercase letter) and theories in IR (uppercase letter).

2. IPT (sometimes also referred to as Normative IR theory or International Ethics) uses traditional Political theory and Moral Philosophy to understand and explain ethical themes, such as justice and community at the international level (Beitz, 1979; Brown, 1992; Cochran, 1999; Erskine, 2008; Frost, 1986; Hutchings, 1999; Linklater, 1990; Nardin, 2008). For an excellent overview please refer to Dunne et al. (2010).

3. Critical Security Studies (CSS) recognizes community formation at the international level. Among the many variants of critical approaches to security, such as Poststructuralism, Feminist and Gender approaches, Securitization theory or Green theory, the so-called 'Welsh School' provides perhaps the closest links to the security community concept (Booth, 2005; Jones, 1999). It argues that community can lift the constraints of war and the threat of war and by enabling individuals and groups to pursue any desired political or other ambitions referred to as 'survival-plus' (Booth, 2007, 39). Booth (2007: 278) thus claims that 'community is the site of security'.

However, the CSS understanding of peaceful community is a highly selective one. First of all, community is understood as stateless forms of free association among individual human beings. Secondly, CSS advocates a notion of community whose identity is based on inclusion rather than exclusion (Booth, 2007). These two prerequisites are very different from Deutsch's concept of security community, which includes both people and states and whose notion of collective identity rests at least in part on the differentiation from outsiders.

4. It is important to note that in IPT, communitarianism is placed in opposition to cosmopolitanism, while in Political theory, communitarianism is typically contrasted with liberalism (Dunne et al., 2010: 43).

5. In IPT, communitarianism treats 'community' and 'the state' synonymously, while Political theory would not make such an assumption. The state-centric character of communitarianism in IPT has led to the introduction of the term 'communitarian realism' in order to distinguish the concept from its political theory counterpart (Erskine, 2008). 
6. Empirical examples include the ASEAN (Acharya, 2005; Bellamy, 2004; Emmerson, 2005), the Australia, New Zealand, United States Security Treaty (ANZUS) (Tow and Albinski, 2002), Southern Latin America (Derghoukassian, 2005; Flemes, 2005; Oelsner, 2003), the Middle East (Bilgin, 2004), the Mediterranean region (Adler and Crawford, 2002), the ECOWAS (Hammerstad, 2005) and the countries of the SADC (Ngoma, 2003).

\section{References}

Acharya A (2001) Constructing a Security Community in Southeast Asia: ASEAN and the Problem of Regional Order. London/New York: Routledge.

Acharya A (2005) Do norms and identity matter? Community and power in Southeast Asia's regional order. Pacific Review 18(1): 95-118.

Adler E and Barnett M (1998a) A framework for the study of security communities. In: Adler E and Barnett M (eds) Security Communities. Cambridge: Cambridge University Press, pp. 29-66.

Adler E and Barnett M (1998b) Security communities in theoretical perspective. In: Adler E and Barnett M (eds) Security Communities. Cambridge: Cambridge University Press, pp. 3-28.

Adler E and Barnett M (1998c) Studying security communities in theory, practice and history. In: Adler E and Barnett M (eds) Security Communities. Cambridge: Cambridge University Press, pp. 413-441.

Adler E and Crawford B (2002) Constructing a Mediterranean region: a cultural approach. Paper presented at the conference on the convergence of civilizations? Constructing a Mediterranean Region, Lisbon, 6-9 June.

Adler E and Greve P (2009) When security community meets balance of power: overlapping regional mechanisms of security governance. Review of International Studies 35(1): 59-84.

Archibugi D (2008) The Global Commonwealth of Citizens: Toward Cosmopolitan Democracy. Princeton, NJ: Princeton University Press.

ASEAN (2004) Vientiane action programme (2004-2010). Available at: http://www.aseansec.org/ VAP-10th\%20ASEAN\%20Summit.pdf (accessed 8 March 2011).

Bayer R (2010) Peaceful transition and democracy. Journal of Peace Research 47(5): 535-546.

Beardsworth R (2011) Cosmopolitanism and International Relations. Cambridge: Polity Press.

Behr H (2010) A History of International Political Theory: Ontologies of the International. New York: Palgrave Macmillan.

Beitz C (1979) Political Theory and International Relations. Princeton, NJ: Princeton University Press.

Bellamy AJ (2004) Security Communities and Their Neighbors: Regional Fortresses or Global Integrators? New York: Palgrave Macmillan.

Bially Mattern J (2005) Ordering International Politics: Identity, Crisis and Representational Force. New York: Routledge.

Bilgin P (2004) Whose 'Middle East'? Geopolitical inventions and practices of security. International Relations 18(1): 25-41.

Bjola C and Kornprobst M (2007) Security communities and the habitus of restraint: Germany and the United States on Iraq. Review of International Studies 33(2): 285-305.

Booth K (ed.) (2005) Critical Security Studies and World Politics. Boulder, CO: Lynne Rienner.

Booth K (2007) Theory of World Security. Cambridge: Cambridge University Press.

Brown C (1992) International Relations Theory. New Normative Approaches. New York: Columbia University Press.

Brown C (2010) Practical Judgement and International Political Theory: Selected Essays. London: Routledge. 
Bueno de Mesquita B and Lalman D (1992) War and Reason. New Haven, CT: Yale University Press.

Bull H (1972) The theory of international politics, 1919-1969. In: Porter B (ed.) The Aberystwyth Papers: International Politics, 1919-1969. London: Oxford University Press, pp. 30-55.

Bull H (1977) The Anarchical Society: A Study of Order in World Politics. Columbia, SC: Columbia University Press.

Burton J (1972) World Society. Cambridge: Cambridge University Press.

Buzan B (1993) From international system to international society: structural realism and regime theory meet the English school. International Organization 47(3): 327-352.

Buzan B (2004) From International to World Society? Cambridge: Cambridge University Press.

Buzan B and Wæver O (2003) Regions and Powers: The Structure of International Security. Cambridge: Cambridge University Press.

Cochran M (1999) Normative Theory in International Relations: A Pragmatic Approach. Cambridge: Cambridge University Press.

Cronin B (1999) Community under Anarchy: Transnational Identity and the Evolution of Cooperation. New York: Columbia University Press.

Derghoukassian K (2005) Security community as the higher stage of regionalism: a southern cone perspective. Paper presented at the annual meeting of the International Studies Association, Hilton Hawaiian Village, Honolulu, HI, 5 March.

Deutsch KW (1954) Political Community at the International Level: Problems of Definitions and Measurement. New York: Doubleday \& Company.

Deutsch KW (1961) Security communities. In: Rosenau JN (ed.) International Politics and Foreign Policy: A Reader in Research and Theory. New York: Free Press, pp. 98-105.

Deutsch KW (1968) The impact of communications upon theory of international relations. In: Said AA (ed.) Theory of International Relations: The Crisis of Relevance. Englewood Cliffs, NJ: Prentice Hall, pp. 74-92.

Deutsch KW (1978) The Analysis of International Relations. 2nd ed. Englewood Cliffs, NJ: Prentice Hall.

Deutsch KW, Burrell SA, Kann RA, et al. (1957) Political Community and the North Atlantic Area: International Organization in the Light of Historical Experience. Princeton, NJ: Princeton University Press.

Dower N (1998) World Ethics: The New Agenda. Edinburgh: Edinburgh University Press.

Doyle MW (1986) Liberalism and world politics. American Political Science Review 80(4): $1151-1169$.

Dunne T, Kurki M and Smith S (2010) International Relations Theories: Discipline and Diversity. 2nd ed. Oxford: Oxford University Press.

Eberwein W-D (1995) The future of international warfare: toward a global security community? International Political Science Review 16(4): 341-360.

Eberwein W-D and Deutsch KW (1990) World modelling and political realities - present and future. International Political Science Review 11(2).

Emmerson DK (2005) Security, community, and democracy in Southeast Asia: analyzing ASEAN. Japanese Journal of Political Science 6(2): 165-185.

Erskine T (2008) Embedded Cosmopolitanism: Duties to Strangers and Enemies in a World of 'Dislocated Communities'. Oxford: Oxford University Press.

Etzioni A (1962) The dialectics of supranational unification. American Political Science Review 56(4): 931-932.

Fierke KM (2007) Critical Approaches to International Security. London: Polity.

Finnemore M and Sikkink K (1998) International norm dynamics and political change. International Organization 52(4): 887-917. 
Flemes D (2005) Creating a regional security community in Southern Latin America: the institutionalisation of the regional defence and security policies. Paper presented at the conference of the World International Studies Committee (WISC) at the Bilgi University, Istanbul, 24-27 August.

Frost M (1986) Towards a Normative Theory of International Relations. Cambridge: Cambridge University Press.

Gilpin R (1981) War and Change in International Politics. Cambridge: Cambridge University Press.

Haas EB (1958) The Uniting of Europe. Stanford, CA: Stanford University Press.

Hammerstad A (2005) Domestic threats, regional solutions? The challenge of security integration in Southern Africa. Review of International Studies 31(1): 69-87.

Harrison E (2010) The democratic peace research program and system-level analysis. Journal of Peace Research 47(2): 155-165.

Hoffmann S (1963) Discord in community: the North Atlantic area as a partial international system. International Organization 17(3): 521-549.

Hollis M and Smith S (1990) Explaining and Understanding International Relations. Oxford: Oxford University Press.

Hutchings K (1999) International Political Theory: Rethinking Ethics in a Global Era. London: Sage.

Jervis R (2002) Theories of war in an era of leading-power peace. American Political Science Review 96(1): 1-14.

Jones RW (1999) Security, Strategy, and Critical Theory. Boulder, CO: Lynne Rienner.

Kacowicz AM (1998) Zones of Peace in the Third World: South America and West Africa in Comparative Perspective. New York: State University of New York Press.

Kaldor M (2003) Global Civil Society: An Answer to War. Cambridge: Polity Press.

Katzenstein PJ (ed.) (1996) The Culture of National Security. New York: Columbia University Press.

Keohane RO (1984) After Hegemony: Cooperation and Discord in the World Political Economy. Princeton, NJ: Princeton University Press.

Keohane RO (1989) International Institutions and State Power: Essays in International Relations Theory. Boulder, CO: Westview Press.

Keohane RO and Nye JS (1977) Power and Interdependence: World Politics in Transition. Boston, MA: Little, Brown and Company.

Koschut S (2012) Friedlicher Wandel ohne Demokratie? Theoretische und empirische Überlegungen zur Bildung einer autokratischen Sicherheitsgemeinschaft. Zeitschrift für Internationale Beziehungen 19(2): 41-69.

Koschut S (2013) Emotional (security) communities: the significance of emotion norms in interallied conflict management. Review of International Studies. Epub ahead of print 28 October 2013. DOI: $10.1017 / \mathrm{S} 0260210513000375$.

Lijphart A (1981) Karl W. Deutsch and the new paradigm in international relations. In: Merritt RL and Russett BM (eds) From National Development to Global Community: Essays in Honor of Karl W. Deutsch. London: George Allen \& Unwin, pp. 233-251.

Linklater A (1990) Beyond Realism and Marxism: Critical Theory and International Relations. Houndmills: Macmillan Press.

Lipson C (2003) Reliable Partners: How Democracies Have Made a Separate Peace. Princeton, NJ: Princeton University Press.

Lund MS and Roig E (1999) Southern Africa: an emerging security community. In: Mekenkamp M, Van Tongeren P and Van de Veen H (eds) Searching for Peace in Africa: An Overview 
of Conflict Prevention and Management Activities. Utrecht: European Centre for Conflict

Prevention, pp. 391-395.

Mearsheimer J (2001) The Tragedy of Great Power Politics. New York: W. W. Norton.

Mitrany D (1943/1966) A Working Peace System. Chicago, IL: Quadrangle Books.

Moravcsik A (1993) Preferences and power in the European community: a liberal intergovernmentalist approach. Journal of Common Market Studies 31(4): 473-524.

Morgenthau H (1948) Politics among Nations: The Struggle for Power and Peace. New York: Alfred A. Knopf.

Mouritzen H (2001) Security communities in the Baltic sea region: real and imagined. Security Dialogue 32(3): 297-310.

Mutimer D (1999) The study of discourse in international relations: a critique of research and methods. European Journal of International Relations 5(2): 225-254.

Nardin T (2008) International ethics. In: Reus-Smit C and Snidal D (eds) The Oxford Handbook of International Relations. Oxford: Oxford University Press, pp. 594-611.

Nathan L (2006) Domestic instability and security communities. European Journal of International Relations 12(2): 275-299.

Ngoma N (2003) SADC: towards a security community? African Security Review 12(3): 17-28.

Oelsner A (2003) Two sides of the same coin: mutual perceptions and security community in the case of Argentina and Brazil. In: Laursen F (ed.) Comparative Regional Integration: Theoretical Perspectives. Aldershot: Ashgate, pp. 185-206.

Onuf N (1989) World of Our Making. Columbia, SC: University of South Carolina Press.

Organski AFK (1968) World Politics. New York: Alfred A. Knopf.

Pentland C (1973) International Theory and European Integration. London: Faber and Faber.

Pouliot V (2008) The logic of practicality: a theory of practice of security communities. International Organization 62(2): 257-288.

Puchala DJ (1981) Integration theory and the study of international relations. In: Merritt RL and Russett BM (eds) From National Development to Global Community: Essays in Honor of Karl W. Deutsch. London: George Allen \& Unwin, pp. 145-165.

Rasmussen AF (2010) Renewing the transatlantic security community in the age of globalisation. Speech by the NATO Secretary General at the Central Military Club, Sofia. Available at: http://www.nato.int/cps/en/natolive/opinions_63773.htm (accessed 8 March 2011).

Rawls J (1971) A Theory of Justice. Oxford: Oxford University Press.

Reus-Smit C (2005) The constructivist challenge after September 11. In: Bellamy AJ (ed.) International Society and Its Critics. Oxford: Oxford University Press, pp. 85-98.

Reus-Smit C and Price R (1998) Dangerous liaisons? Critical international theory and constructivism. European Journal of International Relations 4(3): 259-294.

Risse-Kappen T (1995) Democratic peace - warlike democracies? A social constructivist interpretation of the liberal argument. European Journal of International Relations 1(4): 491-517.

Risse-Kappen T (1996) Collective identity in a democratic community: the case of NATO. In: Katzenstein PJ (ed.) The Culture of National Security. New York: Columbia University Press, pp. 357-399.

Roe P (1999) The intrastate security dilemma: ethnic conflict as a 'Tragedy'? Journal of Peace Research 36(2): 183-202.

Rosecrance R (1993) Trading states in a new concert of Europe.In: Haftendorn H and Tuschhoff $\mathrm{C}$ (eds) America and Europe in an Era of Change. Boulder, CO: Westview Press, pp. 127-145.

Russett BM (1993) Grasping the Democratic Peace: Principles for a Post-Cold War World. Princeton, NJ: Princeton University Press. 
Russett BM (1998) A neo-Kantian perspective: democracy, interdependence and international organizations in building security communities. In: Adler E and Barnett M (eds) Security Communities. Cambridge: Cambridge University Press, pp. 368-394.

Selebi J (1999) Building collaborative security in Southern Africa. African Security Review 8(5): $3-12$.

Shaw TM (1998) African renaissance/African alliance: towards new regionalisms and new realism in the Great Lakes at the start of the twenty-first century. Politeia 17(3): 60-74.

Slantchev BL (2006) Politicians, the media and domestic audience costs. International Studies Quarterly 50(2): 445-477.

Starr H (1992) Democracy and war: choice, learning and security communities. Journal of Peace Research 29(2): 207-213.

Starr H (1997) Democracy and integration: why democracies don't fight each other. Journal of Peace Research 34(2): 153-162.

Thucydides (431 BC/1989) History of the Peloponnesian War (ed D Grene) Chicago, IL: The University of Chicago Press.

Tow W and Albinski H (2002) ANZUS - alive and well after fifty years. Australian Journal of Politics and History 48(2): 153-173.

Tusicisny A (2007) Security communities and their values: taking masses seriously. International Political Science Review 28(4): 425-449.

Väyrynen R (2000) Stable peace through security communities: steps towards theory-building. In: Kacowicz A, Bar-Siman-Tov Y, Elgström O and Jerneck M (eds) Stable Peace Among Nations. Lanham, MD: Rowman and Littlefield, pp.108-129.

Vasquez JA (1995) Why do neighbors fight? Proximity, interaction, or territoriality. Journal of Peace Research 32(3): 277-293.

Vesa U (1993) Back to Deutsch. Integration, peaceful change, and security communities. In: Käkönen J (ed.) Changes in the Northern Hemisphere (Research Report 52). Tampere: Tampere Peace Research Institute, pp. 159-164.

Walt SM (1996) Revolution and War. Ithaca, NY: Cornell University Press.

Waltz K (1979) Theory of International Politics. New York: McGraw-Hill.

Walzer M (1994) Thick and Thin: Moral Argument at Home and Abroad. Notre Dame, IN: Notre Dame University Press.

Weldes J (1999) Constructing National Interests: The United States and the Cuban Missile Crisis. Minneapolis, MN: University of Minnesota Press.

Wendt A (1992) Anarchy is what states make of it: the social construction of power politics. International Organization 46(2): 391-425.

Wendt A (1999) Social Theory of International Politics. Cambridge: Cambridge University Press.

Werner S and Lemke D (1997) Opposites do not attract: the impact of domestic institutions, power, and prior commitments on alignment choices. International Studies Quarterly 41(3): $529-546$.

Wiberg H (2003) A Baltic security community? Paper presented at the international conference 'Deepening the Process of Integration in the Baltic Sea Region: Roles of Actors, Competition between Institutions and the Issue of Identity', Szczecin, 11-14 December. Available at: http:/www.uibk.ac.at/peacestudies/downloads/peacelibrary/balticsea.pdf (accessed 8 March 2011).

Williams MC (2001) The discipline of the democratic peace: Kant, liberalism and the social construction of security communities. European Journal of International Relations 7(4):525-553.

Zannier L (2012) Speech by the OSCE secretary general at the 2012 OSCE security days conference, Vienna, 25 June. Available at: http://www.osce.org/sg/91579 


\section{Author biography}

Simon Koschut is Assistant Professor in International Studies at the University of ErlangenNuremberg (Germany). Previously, he was a Fritz Thyssen Fellow at the Weatherhead Center for International Affairs at Harvard University and a Research Fellow at the German Council on Foreign Relations in Berlin. He has published in numerous peer-reviewed journals including Review of International Studies and Cambridge Review of International Affairs and is the co-editor of 'Friendship and International Relations' (Palgrave, forthcoming). 